\title{
KEPUASAN PASIEN DIABETES MELITUS TERHADAP PERAWATAN PALIATIF: TINGKAT TERENDAH PADA DIMENSI TAMPILAN FISIK
}

\author{
Iin Nur Indah Sari ${ }^{1 *}$, Tuti Nuraini ${ }^{2}$ \\ 1. Rumah Sakit Umum Daerah Budhi Asih, Jakarta Timur, DKI Jakarta 13640, Indonesia \\ 2. Fakultas Ilmu Keperawatan Universitas Indonesia, Kampus UI, Depok 16424, Indonesia \\ *E-mail: iin.nuris@yahoo.co.id
}

\begin{abstract}
Abstrak
Diabetes merupakan penyakit progresif yang tidak hanya membutuhkan perawatan kuratif dan rehabilitatif tetapi juga perawatan paliatif. Salah satu indikator penting tercapainya perawatan paliatif yang efektif adalah kepuasaan pasien. Penelitian ini dilakukan untuk menilai kepuasan pasien diabetes yang mendapatkan perawatan paliatif. Penelitian cross sectional ini melibatkan sampel pasien diabetes di balai asuhan keperawatan di Jabodetabek sebanyak 43 responden. Instrumen yang digunakan adalah modifikasi dan terjemahan Home Care Client Satisfaction Instrument-Revised (HCCSI-R), Client Satisfaction Inventory (CSI), dan Long-form Patient Satisfaction Questionnaire (PSQ-III). Hasil penelitian ini menunjukkan sebanyak $14 \%$ responden merasa cukup puas, $60,5 \%$ merasa puas, dan $25,6 \%$ merasa sangat puas. Dimensi tampilan fisik mendapatkan nilai paling rendah dalam kepuasan pasien di antara dimensi yang lain. Hasil penelitian ini tidak menemukan adanya perbedaan antara karakteristik individu dengan tingkat kepuasan. Penelitian ini merekomendasikan kepada praktisi kesehatan untuk memperhatikan faktor-faktor yang memengaruhi kepuasan pasien.
\end{abstract}

Kata kunci: diabetes, kepuasan pasien, perawatan paliatif

\begin{abstract}
Diabetes Mellitus Patients Satisfaction on Palliative Care: The Lowest Level on Tangibleness Dimension. Diabetes is a progressive disease that needs palliative care aside from curative and rehabilitative. Satisfaction is one of the most important indicators of palliative care, so the measurement of patient satisfaction with treatment is necessary. This study aimed to describe the level of satisfaction of patients with diabetes mellituswho received palliative care. This cross sectional study involved 43 respondents of diabetic patients in nursing care centers in Jabodetabek. Modified and translation of Home Care Client Satisfaction Instrument-Revised (HCCSI-R), Client Satisfaction Inventory (CSI), and the Long-Form Patient Satisfaction Questionnaire (PSQ-III) was used. The results showed that $14 \%$ of respondents reported quite satisfied, 60,5\% satisfied, and 25,6\% very satisfied. Tangibleness dimension was achieved the lowest level of satisfaction. This research also found that there are no significant differences between the characteristics of the respondents with the level of satisfaction $(p>0,05)$. The study recommends healthcare practitioners to deepen their knowledge about palliative care and apply it to health services.
\end{abstract}

Keywords: diabetic, palliative care, patient satisfaction

\section{Pendahuluan}

Transisi demografi dan epidemiologi menyebabkan struktur penduduk semakin menua dan pola penyakit berubah dari penyakit menular ke penyakit tidak menular kronik. Saat ini penyakit tidak menular (PTM) menjadi penyebab utama kematian secara global. Lebih dari dua- pertiga $(70 \%)$ dari populasi global diperkirakan akan meninggal akibat penyakit tidak menular seperti kanker, penyakit jantung, stroke dan diabetes melitus (World Health Organization [WHO], 2011). Salah satu PTM yang terus berlangsung dan menjadi masalah besar dalam kesehatan masyarakat adalah diabetes melitus. Diabetes Melitus (DM) 
merupakan sekelompok penyakit metabolik yang ditandai dengan adanya peningkatan kadar glukosa dalam darah (hiperglikemia) karena kelainan dalam sekresi insulin, aksi insulin atau keduanya (American Diabetes Association [ADA], 2004; Smeltzer \& Bare, 2008).

Diabetes merupakan salah satu penyakit progresif yang memerlukan penanganan lama dan biaya yang besar. Pasien dengan penyakit progresif tidak hanya mengalami berbagai masalah fisik seperti nyeri, sesak nafas, penurunan berat badan, gangguan aktivitas, tetapi juga mengalami gangguan psikososial dan spiritual yang memengaruhi kualitas hidup pasien dan keluarganya. Kebutuhan pasien yang memiliki penyakit pada stadium lanjut tidak hanya pada pemenuhan atau pengobatan gejala fisik, tetapi juga membutuhkan dukungan terhadap kebutuhan psikologis, sosial, dan spiritual yang dikenal sebagai perawatan paliatif (Doyle \& Mac Donald, 2003). Hal ini sejalan dengan Keputusan Kemenkes RI (2007) yang menjelaskan bahwa penyakit kardiovaskuler, kanker, penyakit pencernaan, diabetes, dan PTM lainnya tidak hanya membutuhkan perawatan kuratif dan rehabilitatif tetapi juga membutuhkan perawatan paliatif dalam rangka meningkatkan kualitas pelayanan kesehatan bagi pasien.

Beberapa kendala dapat menghambat pasien dalam mendapatkan pelayanan kesehatan. Keterbatasan fasilitas pada instansi yang menyediakan pelayanan perawatan paliatif tentu saja menjadi salah satu kendala untuk masyarakat dalam mendapatkan perawatan paliatif secara optimal dan akan memengaruhi tingkat kepuasan pasien terhadap pelayanan yang didapatkan. Hasil studi pendahuluan dalam penelitian Meier (2011) menunjukkan bahwa pasien di salah satu hospice di Amerika Serikat menerima perawat berkualitas rendah yang ditandai dengan tidak terpenuhinya kebutuhan psikososial, perawatan pribadi, penanganan gejala, dan biaya yang besar, sehingga pasien beserta keluarga merasa tidak puas.
Hasil studi Elfira (2012) menunjukkan bahwa pasien dan keluarga kurang puas dengan nilai rerata 2,98 terhadap pelayanan perawatan paliatif yang diberikan di Puskesmas Balongsari Surabaya.

Ketidaksesuaian antara harapan masyarakat terhadap perawatan paliatif dengan ketersediaan pelayanan kesehatan dapat memengaruhi tingkat kepuasan. Di sisi lain, keterlibatan konsumen diakui sebagai peran yang diperlukan untuk mengukur dimensi kualitas suatu pelayanan yang nantinya akan menjadi tolok ukur pengembangan institusi penyedia perawatan paliatif (Geron, Smith, Tennstedt, Jette, \& Chassler, 2000). Oleh karena itu, penelitian yang bertujuan untuk mengidentifikasi gambaran tingkat kepuasan pasien DM yang mendapatkan perawatan paliatif perlu dilakukan.

\section{Metode}

Penelitian ini menggunakan desain deskriptif dengan melibatkan 43 pasien DM di Balai Asuhan Keperawatan atau Rumah Perawatan di wilayah Jabodetabek. Responden ini dipilih melalui teknik consecutive sampling mengingat keterbatasan jumlah kunjungan pasien DM di tiap Balai.

Instrumen yang digunakan dalam penelitian ini adalah modifikasi dari Home Care Client Satisfaction Instrument-Revised (HCCSI-R), Client Satisfaction Inventory (CSI), dan Longform Patient Satisfaction Questionnaire (PSQIII). Kuesioner dalam penelitian ini terdiri dari lima bagian yang disusun berdasarkan dimensi kepuasan yaitu dimensi tangibleness (tampilan fisik), dimensi reliability (keandalan), dimensi responsiveness (daya tanggap), dimensi empathy (empati) dan dimensi assurance (jaminan) dengan total 35 butir pernyataan yang dapat diisi oleh pasien DM yang mendapatkan perawatan paliatif. Tiap butir dinilai menggunakan skala Likert dari "sangat puas" sampai "sangat tidak puas". Validitas instrumen dari seluruh 34 pernyataan memiliki $r>0,396$. Hal 
ini menunjukkan bahwa 34 pernyataan dinyatakan valid. Uji reliabilitas instrumen menghasilkan nilai Cronbach alpha> 0,964 yang menunjukkan bahwa instrumen dalam penelitian ini bersifat reliabel.

\section{Hasil}

Karakteristik responden paling banyak dewasa akhir $(39,5 \%)$, berjenis kelamin perempuan $(55,8 \%)$, berpendidikan perguruan tinggi $(37,2 \%)$, bekerja sebagai pegawai swasta $(46,5 \%)$, dan berpenghasilan lebih atau sama dengan $2.700 .000(37,2 \%)$. Secara rinci data tentang karakteristik ini dapat dilihat pada tabel 1 .

Tabel 1. Karakteristik Responden

\begin{tabular}{lcc}
\hline \multicolumn{1}{c}{ Karakteristik } & Frekuensi & $\begin{array}{c}\text { Presentase } \\
(\boldsymbol{\%})\end{array}$ \\
\hline Usia & & \\
Dewasa Awal & 8 & 18,6 \\
Dewasa Tengah & 12 & 27,9 \\
Dewasa Akhir & 17 & 39,5 \\
Lansia & 6 & 14 \\
Jenis Kelamin & & \\
Laki-laki & 19 & 44,2 \\
Perempuan & 24 & 55,8 \\
Pendidikan & & \\
SD & 8 & 18,6 \\
SMP & 4 & 27,9 \\
SMA & 15 & 34,9 \\
Perguruan Tinggi & 16 & 37,2 \\
Pekerjaan & & \\
Pegawai Negeri & 6 & 14 \\
Pegawai Swasta & 18 & 41,9 \\
Wiraswasta & 6 & 14,0 \\
Tidak bekerja & 13 & 9,3 \\
Pendapatan & & \\
>2.700.000 & 15 & 37,2 \\
>2.700.000-5.000.000 & 12 & 27,9 \\
>5.000.000-7.500.000 & 9 & 20,9 \\
>7.500.000 & 7 & 16,3 \\
\hline
\end{tabular}

Hasil penelitian menunjukkan bahwa mayoritas responden berada pada rentang merasa puas $(60,5 \%)$. Data tersebut dapat dilihat pada gambar 1.

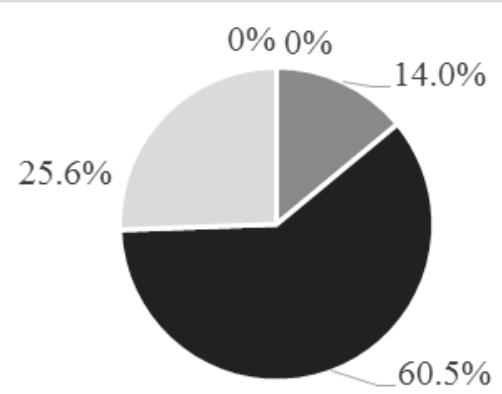

$$
\begin{array}{ll}
\text { - Sangat Tidak Puas } & \text { - Tidak Puas } \\
\text { - Cukup Puas } & \text { - Puas } \\
\text { - Sangat Puas } &
\end{array}
$$

Gambar 1. Diagram Tingkat Kepuasan Responden

Dimensi tingkat kepuasan pasien dapat dilihat pada tabel 2. Hasil penelitian menunjukkan bahwa $65,1 \%$ responden merasa puas pada dimensi tangibleness (tampilan fisik), 67,4\% responden merasa puas pada dimensi reliability (keandalan), 60,5\% responden merasa puas pada dimensi responsiveness (daya tanggap), 67,4\% responden merasa puas pada dimensi empathy (empati), dan 62,8\% responden merasa puas pada dimensi assurance (jaminan).

\section{Pembahasan}

Karakteristik Responden. Hasil penelitian menunjukan bahwa mayoritas responden berada dalam rentang dewasa akhir (46-60 tahun). Penyakit diabetes pada umumnya dialami oleh seorang yang sudah memasuki dewasa akhir. Seseorang yang berusia lebih dari 45 tahun memiliki peningkatan risiko terhadap terjadinya DM dan intoleransi glukosa yang disebabkan oleh faktor degeneratif yaitu menurunnya fungsi tubuh, khususnya kemampuan sel $\beta$ dalam memproduksi insulin untuk memetabolisme glukosa (Sujaya, 2009). 
Tabel 2. Tingkat Kepuasan Responden pada Tiap Dimensi

\begin{tabular}{lccccc}
\hline \multirow{2}{*}{ Variabel } & \multicolumn{5}{c}{ Kategori Tingkat Kepuasan } \\
\cline { 2 - 6 } & $\begin{array}{c}\text { Sangat Tidak } \\
\text { Puas }\end{array}$ & Tidak Puas & Cukup Puas & Puas & $\begin{array}{c}\text { Sangat } \\
\text { Puas }\end{array}$ \\
\hline Dimensi tangibleness (tampilan fisik) & 1 & 1 & 9 & 28 & 4 \\
& $2,3 \%$ & $2,3 \%$ & $20,9 \%$ & $65,1 \%$ & $9,3 \%$ \\
Dimensi reliability (kehandalan) & 0 & 0 & 4 & 29 & 10 \\
& $0,0 \%$ & $0,0 \%$ & $9,3 \%$ & $67,4 \%$ & $23,3 \%$ \\
Dimensi responsiveness (daya tanggap) & 0 & 0 & 6 & 26 & 11 \\
& $0,0 \%$ & $0,0 \%$ & $14,0 \%$ & $60,5 \%$ & $25,6 \%$ \\
Dimensi empathy (empati) & 0 & 0 & 3 & 29 & 11 \\
& $0,0 \%$ & $0,0 \%$ & $7,0 \%$ & $67,4 \%$ & $25,6 \%$ \\
Dimensi assurance (jaminan) & 0 & 0 & 5 & 27 & 11 \\
\hline
\end{tabular}

Hasil penelitian ini didukung oleh Richardo dan Darmayanti (2014) di Manado. Berdasarkan penelitian tersebut, sepuluh perempuan usia produktif di Puskesmas Wawonasa Manado menunjukkan bahwa 50\% berusia 4660 tahun. Hasil penelitian ini juga didukung Kurnia (2012) yang menjelaskan bahwa ada hubungan yang signifikan antara umur dengan risiko terjadinya diabetes. Kelompok umur kurang dari 45 tahun merupakan kelompok yang kurang berisiko menderita DM Tipe 2. Risiko pada kelompok ini $72 \%$ lebih rendah dibanding kelompok umur 45 tahun atau lebih.

Hasil penelitian menunjukkan bahwa 55,8\% pasien berjenis kelamin perempuan sedangkan $44,2 \%$ berjenis kelamin laki-laki. Namun, hasil penelitian ini berbeda dengan hasil penelitian yang dilakukan oleh Wong, Gucciardi, Li, dan Grace (2005) di Kanada. Berdasarkan penelitian tersebut, penderita diabetes laki-laki lebih banyak dibandingkan dengan penderita perempuan. Sebanyak 561 orang yang menghadiri Diabetes Education Centre di Toronto Western Hospital, 53\% laki-laki dan $47 \%$ perempuan. Perbedaan hasil penelitian tersebut dapat disebabkan oleh perbedaan budaya di tempat penelitian yang dapat memengaruhi pola hidup pada laki-laki atau perempuan pada umumnya.
Pola hidup yang dimaksud adalah pola makan dan olahraga yang bisa menjadi faktor pemicu terjadinya penyakit diabetes.

Hepp, Spindler, dan Milos (2005) mengidentifikasi bahwa masalah pola makan lebih banyak ditemukan pada perempuan dibanding lakilaki. Secara umum, olahraga dianggap sebagai domain laki-laki (Riemer \& Visio, 2003), namun lebih khusus, kegiatan olahraga digolongkan sebagai olahraga maskulin, feminin, atau netral. Kegiatan ekspresif (misalnya menari dan senam) secara konsisten dikategorikan sebagai olahraga feminin, tenis atau berenang sebagai olahraga netral, dan olahraga beladiri sebagai olahraga maskulin.

Nursiswati, Prawesti, dan Sihombing (2012) dalam penelitiannya di Jakarta mengidentifikasi bahwa dari 92 pasien diabetes, $84,78 \%$ berjenis kelamin perempuan. Perempuan lebih berisiko terkena diabetes karena wanita berpeluang lebih besar untuk mengalami peningkatan indeks masa tubuh dibandingkan lakilaki. Selain itu, sindroma siklus bulanan (premenstrual syndrome) dan pasca menopause juga membuat distribusi lemak tubuh menjadi terakumulasi akibat proses hormonal. Terjadinya akumulasi lemak tubuh menyebabkan otot 
akan makin resistensi terhadap kerja insulin, sehingga wanita berisiko menderita DM tipe 2 (Kurnia, 2012).

Hasil penelitian menunjukkan bahwa $34,9 \%$ pasien berpendidikan SMA, dan 37,2\% berpendidikan sarjana. Berdasarkan hasil penelitian, didapatkan bahwa rerata pasien memiliki latar belakang pendidikan yang tinggi. Namun, hasil penelitian ini berbeda dengan hasil penelitian yang dilakukan oleh Kurnia (2012) yang menemukan, 61,29\% pasien diabetes melitus di Puskesmas Cengkareng berlatar belakang pendidikan yang rendah. Menurut Irawan (2010), tingkat pendidikan berpengaruh terhadap kejadian penyakit DM karena masyarakat berpendidikan tinggi akan memiliki banyak pengetahuan tentang kesehatan, sehingga mereka memiliki kesadaran tinggi dalam menjaga kesehatan.

Masyarakat yang berpendidikan tinggi seharusnya memiliki banyak pengetahuan tentang kesehatan dan memiliki kesadaran tinggi untuk menjaga kesehatannya. Namun, saat ini tingkat pendidikan yang tinggi tidak menjamin masyarakat dapat sadar menjaga kesehatannya. Tidak sedikit dari mereka juga memiliki gaya hidup yang kurang baik. Gaya hidup yang dimaksud seperti kebiasaan mengonsumsi makanan yang berisiko seperti makanan cepat saji atau makanan instan dengan tingkat glukosa tinggi, minuman berkafein, minuman bersoda, makanan berlemak, jeroan dan lain-lain. Kebiasaan mengkonsumsi alkohol dan merokok merupakan salah satu gaya hidup kurang sehat yang dapat menyebabkan terjadinya DM (Kurnia, 2012).

Hasil penelitian menunjukkan bahwa $41 \%$ pasien memiliki pekerjaan sebagai pegawai swasta. Hasil penelitian menunjukkan $62,8 \%$ berpenghasilan lebih dari Rp2.700.000,- atau di atas upah minimum regional DKI Jakarta. Bahkan sebanyak 37,2\% berpendapatan antara Rp5.000.000 hingga Rp7.500.000. Biaya perawatan paliatif untuk luka diabetes cukup mahal dan membutuhkan dana yang besar untuk me- menuhi kebutuhan selama perawatan. Mahalnya biaya perawatan paliatif ini dapat ditanggulangi dengan adanya asuransi kesehatan nasional baik yang bersifat mandiri maupun karena fasilitas dari pekerjaan. Smith, Brick, O'Hara, dan Normand (2014) menelaah biaya perawatan paliatif pada berbagai tatanan, seperti di rumah sakit, di rumah atau di Hospice. Hasil telaah mereka menyebutkan bahwa biaya perawatan paliatif relatif tidak mahal di berbagai tatanan tersebut dibandingkan dengan bentuk perawatan informal lainnya. Perawatan medis dengan bentuk informal mungkin belum terlalu banyak dikenal di Indonesia sehingga biayanya sering dibandingkan secara head to head dengan perawatan medis yang formal.

Tingkat Kepuasan Responden. Hasil penelitian tentang gambaran tingkat kepuasan pasien secara umum menunjukkan sebanyak $60,5 \%$ responden merasa puas terhadap pelayanan yang diberikan. Jika dilihat tingkat kepuasan berdasarkan tiap dimensi, maka didapatkan bahwa pasien merasa puas pada semua dimensi pelayanan yang diberikan yakni dimensi tangibleness (tampilan fisik), dimensi reliability (keandalan), dimensi responsiveness (daya tanggap), dimensi empathy (empati), dan dimensi assurance (jaminan). Hasil penelitian ini sejalan dengan penelitian yang dilakukan Wijayanti, Kristanti, dan Setiyarini (2014) yang menemukan bahwa pasien dan keluarga memiliki tingkat kepuasan yang tinggi terhadap pelayan perawatan paliatif di RSUD Dr. Sardjito Yogyakarta. Nilai kepuasan yang tertinggi terletak pada aspek perawatan psikososial.

Dimensi tangibleness (tampilan fisik) mendapatkan nilai terendah dibandingkan dengan dimensi yang lainnya. Dimensi ini meliputi tampilan lingkungan dalam perawatan paliatif. Lingkungan juga memengaruhi kenyamanan dan kepuasan pasien. Dimensi tampilan fisik bersama dengan tingkat respon, dan empati berpengaruh paling besar pada kualitas layanan secara keseluruhan. Ditemukan ada 
hubungan yang positif dan signifikan antara kualitas layanan secara keseluruhan, kepuasan pasien dan niat perilaku mereka (Ramez, 2012).

Masyarakat atau pasien menilai sebuah pelayanan bermutu jika suatu pelayanan kesehatan dapat memenuhi kebutuhan yang diharapkan pada lima dimensi pelayanan yang telah disebutkan di atas. Beberapa contoh harapan yang diinginkan pasien adalah seperti memberikan pelayanan secara sopan dan santun, tepat waktu, tanggap, mampu menyembuhkan keluhannya, serta mampu mencegah berkembangnya atau meluasnya penyakit. Menurut Kotler (2005), kepuasan konsumen diukur berdasarkan tingkat harapan konsumen tentang produk dan pelayanan dengan pelayanan aktual yang diberikan. Pasien akan merasa puas jika pelayanan keperawatan yang diberikan sesuai dengan kebutuhan dan harapan pasien.

\section{Kesimpulan}

Penelitian ini mengidentifkasi tingkat kepuasan masyarakat yang mendapatkan perawatan paliatif. Jenis penyakit kronis yang membutuhkan perawatan paliatif cukup beragam, termasuk diabetes melitus. Berdasarkan hasil penelitian diperoleh gambaran tingkat kepuasan masyarakat terhadap perawatan paliatif yang didapatkan. Hasil penelitian menunjukkan bahwa secara umum semua pasien merasa puas dengan pelayanan yang diberikan. Semua pasien merasa puas terhadap semua dimensi pelayanan yakni dimensi tangibleness (tampilan fisik), dimensi reliability (keandalan), dimensi responsiveness (daya tanggap), dimensi empathy (empati) dan dimensi assurance (jaminan). Dimensi tangibleness (tampilan fisik) mendapatkan skor terendah karena lingkungan fisik yang diberikan masih terbatas dan sempit.

Kepuasan pasien diukur berdasarkan tingkat harapan pasien terhadap pelayanan yang diberikan dan perubahan kesehatan yang didapat- kan. Pasien akan merasa puas jika pelayanan keperawatan yang diberikan sesuai dengan kebutuhan dan harapan pasien. Oleh karena itu, perawat perlu memperhatikan faktor-faktor yang memengaruhi kepuasan pasien, antara lain faktor lingkungan fisik (TN, INR, AM).

\section{Referensi}

Abraham, M. (2003). Motivasi dan kepribadian. Jakarta: Midas Surya Grafindo.

Depkes, RI. (2001). Pembangunan kesehatan masyarakat di Indonesia. Jakarta: Badan Litbangkes, Depkes RI.

Damayanti, N., \& Richardo. (2014). Analisis faktor resiko penyebab terjadinya diabetes mellitus tipe 2 pada wanita usia produktif di Puskesmas Wawonosa. Jurnal e-Biomedik (eBM), 2 (2), 404-412.

Doyle, D., Hanks, G.W.C., \& MacDonald, N. (2003). Oxford textbook of palliative medicine (3rd Ed.). New York: Oxford Medical Publications.

Elfira, S. (2012). Gambaran kualitas hidup dan kepuasan pasien kanker terhadap peran farmasis dan perawatan paliatif di puskesmas balongsari Surabaya. Surabaya: Fakutas Ilmu Keperawatan Universitas Surabaya.

Geron, S.M., Smith, K., Tennstedt, S., Jette, A., \& Chassler, D. (2000). The home care satisfaction measure: A client-centered approach to assessing the satisfaction of frail older adults with home care services. Journal of Gerontology: Social Sciences, 55 (5), 259 270. Diperoleh dari http://psychsocgerontology .oxfordjournals.org/content/55/5/S259.full.pdf

Gunarsa, S. (2008). Psikologi perawatan. Jakarta: Gunung Mulia.

Hepp, U., Spindler, A., \& Milos, G. (2005). Eating disorder symptomatology and gender role orientation. International Journal of Eating Disorders, 37 (3), 227-233. doi: 10.1002/eat.2 0087 
Hidayati, A.N. (2014). Analisis hubungan karakteristik pasien dengan kepuasan pelayanan rawat jalan Semaran Eye Center (SEC) Rumah Sakit Islam Sultan Agung. Jurnal Kesehatan Masyarakat, 2 (1), 9-14.

International Diabetes Federation. (2008). Diabetes prevalence: World diabetes day. Diperoleh dari http/www.diabetes@idf.int.

Irawan, D. (2010). Prevalensi dan faktor risiko kejadian diabetes melitus tipe 2 di daerah urban Indonesia (analisa data sekunder riskesdas 2007) (Tesis, tidak dipublikasikan). Fakultas Ilmu Keperawatan Universitas Indonesia, Depok Jawa Barat.

Kotler, P. (2005). Manajemen pemasaran, jilid 1. Jakarta: PT. Indeks Kelompok Gramedia.

Kurnia, S. (2012). Faktor risiko kejadian diabetes mellitus tipe II di Puskesmas Kecamatan Cengkareng Jakarta Barat tahun 2012. Jurnal Ilmiah Kesehatan, 5 (1), 6-11.

Meier, D.E. (2011). Increased access to palliative care and hospice services: Opportunities to improve value in health care. The Milbank Quarterly, 89 (3), 343-380. doi:10.1111/j.1468 0009.2011.00632.x

Nursiswati, Prawesti, A., \& Sihombing, D. (2012). Gambaran perawatan kaki dan sensasi sensorik kaki pada pasien diabetes mellitus tipe 2 di poliklinik DM RSUD. Bandung: Fakultas Ilmu Keperawatan Universitas Padjadjaran.

Oroh, M. E., Pondaag, L., \& Rompas, S. (2014). Faktor-faktor yang berhubungan dengan tingkat kepuasan pasien rawat inap terhadap pelayanan keperawatan di ruang interna RSUD Noongan. Manado: Fakultas Kedokteran Universitas Sam Ratulangi.

Ramez, W.S. (2012). Patients' perception of health care quality, satisfaction and behavioral intention: An empirical study in Bahrain. International Journal of Business and Social Science, 3 (18), 131-141. Diperoleh dari http://ijbssnet.com/journals/Vol_3_No_18_Spe cial_Issue_September_2012/15.pdf
Riemer, B.A., \& Visio, M.E. (2003). Gender typing of sports: An investigation of Metheny's classification. Research Quarterly for Exercise \& Sport, 74 (2), 193-204. Diperoleh dari https://www.ncbi.nlm.nih.gov/ pubmed/12848232

Rustanti, M. (2003). Hubungan antara karakteristik dan persepsi pasien tentang mutu pelayanan fisioterapi dengan tingkat kepuasan pasien rawat jalan fisioterapi pada RSO "Prof Dr. $R$ Soeharso" Surakarta Tahun 2003. Semarang: Fakultas Ilmu Keperawatan Universitas Diponegoro.

Smith, S., Brick, A., O’Hara, S., \& Normand, C. (2014). Evidence on the cost and costeffectiveness of palliative care: A literature review. Palliative Medicine, 28 (2), 130-150. doi: 10.1177/0269216313493466

Sujaya, I.N. (2009). Pola konsumsi makanan tradisional Bali sebagai faktor risiko diabetes melitus tipe 2 di Tabanan. Jurnal Skala Husada, 6 (1), 75-81.

Wijayanti, M.N., Kristanti, M.S., Setiyarini, S. (2014). Gambaran kepuasan keluarga pasien kanker paliatif terhadap pelayanan perawatan paliatif di RSUP DR. Sardjito Yogyakarta [Abstrak] (Skripsi, tidak dipublikasikan). PSIK-FK Universitas Gajah Mada, Yogyakarta. Diperoleh dari http://etd.reposito ry.ugm.ac.id/downloadfile/73614/potongan/S1 -2014-299814-abstract.pdf

Wong, M., Gucciardi, E., Li, L., \& Grace, S.L. (2005). Gender and nutrition management in type 2 diabetes. Canadian Journal of Dietetic Practice and Research, 66 (4), 215-220. doi: 10.3148/66.4.2005.215

World Health Organization. (2011). Global status report non-communicable diseases 2010. Geneva: World Health Organization.

World Health Organization. (2011). Noncommunicable disease country profiles 2011 WHO global report. Geneva: World Health Organization. 